\title{
Evaluation of Models of Border Irrigation Recession
}

\author{
R. S. RAM*; V. P. SINGH†
}

Recession characteristics play an important role in the design of border irrigation systems. This is particularly true of those borders which have closed downstream ends where surface storage is large even after the cessation of inflow. This paper examines some of the existing models of border irrigation recession. Using experimental data these models are evaluated and compared with each other in regard to their ability to predict recession flow.

\section{Introduction}

Although recession flow during irrigation has long been a subject of theoretical and experimental research, relatively little is known about it. It is usually assumed that when the inflow at the upstream of a border is cut off, water recedes first vertically and then horizontally due to the combined effect of infiltration and surface flow, ${ }^{1}$ as shown in Fig. 1 . Should there be a bund at the downstream end, water gets impounded and recedes predominantly by infiltration after cessation of horizontal recession ${ }^{2}$ as shown in Fig. 2. The approaches to modelling recession flow are principally of 3 kinds: (1) hydraulic, (2) volume balance and (3) empirical.

The equations of continuity and momentum form the basis of a hydraulic approach. Solution of these equations is complicated by a lack of a prior knowledge of the boundaries of the solution domain. These boundaries must be determined along with the solution, and are responsible for

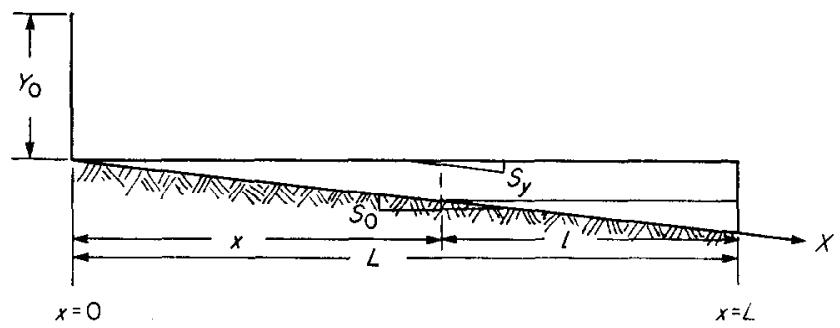

Fig. 1. Schematic surface profiles during vertical and horizontal recession phases in a freely draining border

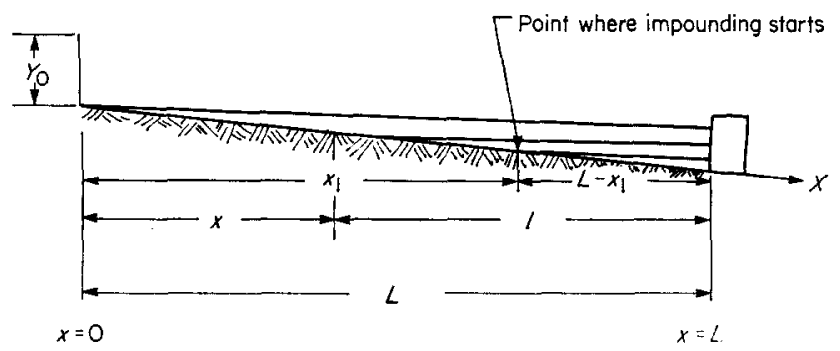

Fig. 2. Schematic surface profiles during vertical and horizontal recession phases in a border with closed end

\footnotetext{
* Department of Civil Engineering, Mississippi State University, Mississippi 39762, U.S.A.

† Department of Civil Engineering, Louisiana State University, Baton Rouge, Louisiana 70803, U.S.A.

Received 5 February 1981 ; accepted in revised form 18 January 1982
} 


\section{NOTATION}

\begin{tabular}{|c|c|}
\hline$A_{1}$ & $=-\frac{1}{2} \alpha_{1}\left(m_{0} S_{0}\right)^{1 / 2} L^{-1 / 2}$ \\
\hline$A_{2}$ & $=-\frac{1}{2} \alpha_{2}\left(m_{0} S_{0}\right)^{2 / 3} L^{-1 / 3}$ \\
\hline$a$ & exponent in the Kostyakov cumulative infiltration equation (7) \\
\hline$B$ & $=-f / 2 m_{0} S_{0} L$ \\
\hline$b$ & exponent in horizontal recession equation (22) \\
\hline$C$ & Chezy's roughness coefficient, $\mathrm{m}^{1 / 2} / \mathrm{s}$ \\
\hline$f$ & average infiltration rate, $\mathrm{m} / \mathrm{s}$ \\
\hline$f_{c}$ & minimum infiltration rate, $\mathrm{m} / \mathrm{s}$ \\
\hline$f_{s}$ & average infiltration rate, $\mathrm{m} / \mathrm{s}$ \\
\hline$f_{1}$ & $f$ defined by Eqn (6) \\
\hline$f_{2}$ & $f$ defined by Eqn (6) \\
\hline$f_{3}$ & $f$ defined by Eqn (9) \\
\hline$f_{4}$ & $f$ defined by Eqn (9) \\
\hline$f_{5}$ & $f$ defined by Eqn (17) \\
\hline$f_{6}$ & $f$ defined by Eqn (17) \\
\hline$F$ & quantity defined by Eqn (12) \\
\hline$I$ & cumulative infiltration (m) in Eqns (7) and (23) \\
\hline$I_{1}$ & cumulative infiltration (m) at end of $T_{1}$ \\
\hline$I_{2}$ & cumulative infiltration (m) at end of $T_{2}$ \\
\hline$I_{3}$ & cumulative infiltration $(\mathrm{m})$ at end of $T_{3}$ \\
\hline$I_{r_{1}}$ & instantaneous rate of infiltration $(\mathrm{m} / \mathrm{s})$ at end of $T_{1}$ \\
\hline$I_{r_{2}}$ & instantaneous rate of infiltration $(\mathrm{m} / \mathrm{s})$ at end of $T_{2}$ \\
\hline$I_{r_{3}}$ & instantaneous rate of infiltration $(\mathrm{m} / \mathrm{s})$ at end of $T_{\mathrm{a}}$ \\
\hline$I_{L}$ & cumulative infiltration (m) at time $t_{t}-t_{L}$ \\
\hline$I_{L-l}$ & cumulative infiltration (m) at time $t_{t}-t_{L-1}$ \\
\hline$I_{R}$ & cumulative infiltration (m) at time $T_{1}-t_{L}$ \\
\hline$I_{l}$ & cumulative infiltration (m) at time $T_{1}-t_{L-l}$ \\
\hline$K_{h}$ & constant in Eqn (22) \\
\hline$K_{i}$ & infiltration constant, $\mathrm{m} / \mathrm{s}^{a}$ \\
\hline$K_{r}$ & recession constant, $\mathrm{s}$ \\
\hline$L$ & total length of border, $\mathrm{m}$ \\
\hline$l$ & length of horizontal recession $(\mathrm{m})$ measured from downstream end \\
\hline$m_{0}$ & slope constant \\
\hline$n$ & Manning's roughness coefficient \\
\hline$q_{0}$ & inflow rate, $\mathrm{m}^{3} \mathrm{~m}^{-1} \mathrm{~s}^{-1}$ \\
\hline$q_{1}$ & $=q_{0}-f_{s} L$ \\
\hline$r$ & constant in Eqn (22) \\
\hline$R_{\mathrm{l}}$ & quantity defined by Eqn (15) \\
\hline$R_{L}$ & quantity defined by Eqn (13) \\
\hline$S$ & surface storage, $\mathrm{m}^{3}$ \\
\hline$S_{0}$ & border slope, $\mathrm{m} / \mathrm{m}$ \\
\hline$S_{y}$ & $=Y_{n} / L$ \\
\hline$t$ & $\begin{array}{l}\text { time of horizontal recession measured after completion of vertical recession for } \\
\text { horizontal recession length }(x) \text { from upstream end, min }\end{array}$ \\
\hline$t_{x}$ & time of advance to point $x$ measured from upstream end, min \\
\hline$t_{r}$ & $\begin{array}{l}\text { time of horizontal recession measured after completion of vertical recession for } \\
\text { length } l \text { measured from downstream end, min }\end{array}$ \\
\hline
\end{tabular}




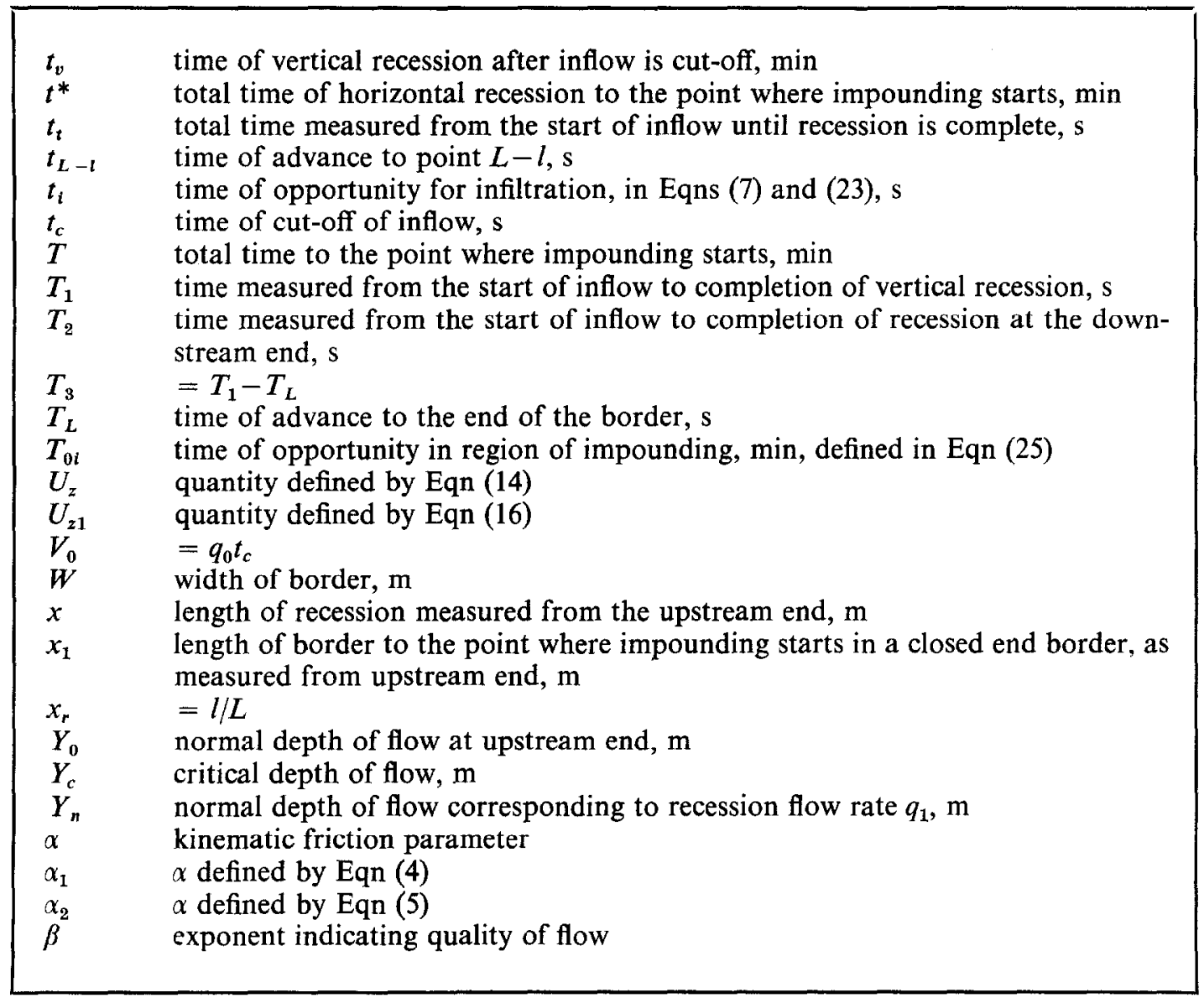

the arising of free boundary problems in irrigation hydraulics, as illustrated by Sherman and Singh. ${ }^{3}$ Several investigators have employed these equations to describe recession flow. By utilizing continuity and momentum equations, $\mathrm{Su}^{4}$ developed a simplified expression for vertical recession. An expression for horizontal recession was, however, developed from the continuity equation alone. In a similar vein, several other investigators ${ }^{5-8}$ developed mathematical models to describe recession flow, subject to infiltration, under various conditions.

The equations of hydraulics are difficult to solve, even numerically; their computer solutions are often expensive. Further, the model results may not always agree well with field measurements of recession because of inaccuracies associated with measurements in estimation of infiltration, roughness and geometric characteristics. These difficulties have led to simplified hydraulic models: (1) kinematic wave models ${ }^{3,9}$ and (2) zero inertia models. ${ }^{10,11}$

On the other hand, the volume balance approach is based on a spatially lumped form of the continuity equation and a storage discharge relationship, linear or non-linear, and has been employed by several investigators. ${ }^{12-14}$ The parameters in the storage equation are evaluated empirically. In an empirical approach algebraic equations are postulated for recession flow where the constants are correlated with border hydraulic and geometric characteristics. ${ }^{15}$

In this paper, an attempt is made to examine critically some of the simplified recession models. These models are evaluated using limited experimental data and compared with each other in the light of their validity for applications in irrigation design. 


\section{Models of vertical recession}

The vertical recession time, as shown in Figs 1 and 2, is the time from the cessation of inflow to the time when the depth of flow at the upstream end becomes zero. Vertical recession models, currently in use, are considered below. Only pertinent remarks are made about the models; for their details see the references cited.

\subsection{SWP model}

The model developed by Shockley, Woodward and Phelan, ${ }^{16}$ henceforth designated as the SWP model, expresses the time of vertical recession as

$$
t_{v}=\frac{Y_{0}^{2}}{120 S_{0} q_{0}}
$$

where $t_{v}$ is the time of vertical recession ( $\mathrm{min}$ ), $Y_{0}$ is the normal depth of flow at the upstream end (in m), as shown in Fig. 1, $S_{0}$ is the border slope $(\mathrm{m} / \mathrm{m})$ and $q_{0}$ is the inflow rate $\left(\mathrm{m}^{3} \mathrm{~m}^{-1} \mathrm{~s}^{-1}\right)$. From now on, a symbol will be defined when it appears for the first time. For easy referencing, all the symbols are given in the Notation.

Utilizing the equation of continuity Chen ${ }^{1}$ developed a similar model. The SWP model is based on 2 assumptions: (1) there exists a free water surface with a depth $Y_{0}$ at the upstream end after inflow is cut off and (2) the water recedes with a rate $q_{0}$.

\subsection{SCS model}

The Soil Conservation Service of the U.S. Department of Agriculture, ${ }^{17}$ SCS in short, used a modified form of Eqn (1),

$$
t_{v}=\frac{q_{0}^{0 \cdot 2} n^{1 \cdot 2}}{120 S_{0}^{1 \cdot 6}}
$$

where $n$ is Manning's roughness coefficient.

\subsection{Strelkoff model}

Strelkoff ${ }^{13}$ used the following relationship for the time of vertical recession:

$$
t_{v}=\frac{Y_{0} L}{120 q_{0}},
$$

where $L$ is length of the border (m).

The principal assumptions of this model are: (1) the surface profiles at the time when inflow is cut-off and the vertical recession is complete are straight lines and (2) the triangular volume of length $L$ and upstream height $Y_{0}$ recedes by infiltration and surface outflow at the combined rate $q_{0}$. If $L=Y_{0} / S_{0}$, then Eqn (3) reduces to Eqn (1). The assumptions leading to Eqns (1)-(3) may not generally hold in flat borders.

\section{Models of horizontal recession}

\subsubsection{Sherman-Singh model}

\subsection{Kinematic approach}

Utilizing kinematic wave theory Sherman and Singh ${ }^{3}$ derived explicit expressions for the time of horizontal recession for a free draining border as

$$
t=\frac{1}{60}\left[\frac{x}{\alpha f^{\beta-1}}\right]^{1 / \beta},
$$


where $\beta$ is $5 / 3$ for Manning's relation and 3/2 for Chezy's relation. Accordingly, $a$ will change and is designated as $\alpha_{1}$ for Chezy's relation and $\alpha_{2}$ for Manning's relation. For $\alpha_{1}, \alpha_{2}$ and $\beta$ the resulting equations are

$$
t=\frac{1}{60}\left[\frac{x}{\alpha_{1} f^{1 / 2}}\right]^{2 / 3}, \quad \alpha_{1}=C S_{0}^{1 / 2}
$$

and

$$
t=\frac{1}{60}\left[\frac{x}{\alpha_{2} f^{2 / 3}}\right]^{3 / 5}, \quad \alpha_{2}=\frac{1}{n} S_{0}^{1 / 2},
$$

where $t$ is the time of horizontal recession (min) for length $x(\mathrm{~m})$ measured from the upstream end, $f$ is the average infiltration rate $(\mathrm{m} / \mathrm{s}), n$ is Manning's roughness coefficient $\left(\mathrm{s} / \mathrm{m}^{1 / 3}\right)$ and $C$ is Chezy's roughness coefficient $\left(\mathrm{m}^{1 / 2} / \mathrm{s}\right)$.

The principal limitation of Eqn (4) or (5) lies in the assumption of constant infiltration rate $f$ which is not explicitly defined. Since infiltration rate is not constant during irrigation, we consider the following definitions for $f$, designated as $f_{1}$ and $f_{2}$ :

$$
f_{1}=\frac{1}{2}\left(\frac{I_{1}}{T_{1}}+\frac{I_{2}}{T_{2}}\right), \quad f_{2}=\frac{1}{2}\left(I_{r_{1}}+I_{r_{2}}\right) .
$$

Cumulative infiltration $I_{1}$ and $I_{2}$ (both in $\mathrm{m}$ ) and instantaneous rates $I_{r_{1}}$ and $I_{r_{3}}$ (both in $\mathrm{m} / \mathrm{s}$ ) at the end of vertical recession time $T_{1}(\mathrm{~s})$ and completion of horizontal recession time $T_{2}(\mathrm{~s})$, respectively, can be calculated by using the Kostyakov infiltration equation, ${ }^{18}$

$$
I=K_{i} t_{i}^{a}
$$

where $I$ is the cumulative infiltration (m) for time $t_{l}(\mathrm{~s})$ and $K_{i}\left(\mathrm{~m} / \mathrm{s}^{a}\right)$ and $a$ are infiltration constants.

\subsubsection{Wu model}

\subsection{Volume balance approach}

$\mathrm{Wu}^{12}$ expressed the time of horizontal recession as

$$
t_{r}=\frac{5}{180} K_{r} \ln \left(\frac{f_{c} K_{r}^{2 \cdot 5} \alpha_{2}^{1.5}+L^{1.5}}{f_{c} K_{r}^{2 \cdot 5} \alpha_{2}^{1.5}+l^{1.5}}\right),
$$

where $t_{\mathrm{r}}$ is the time of horizontal recession ( $\mathrm{min}$ ) for length $l(\mathrm{~m})$ measured from the downstream end. In Eqn (8) $f_{c}(\mathrm{~m} / \mathrm{s})$ is assumed as minimum infiltration rate. This assumption is reasonable if irrigation time is sufficiently long. The accuracy of Eqn (8) may depend upon a correct determination of the recession constant $K_{r}(\mathrm{~s})$ which may require series of experimental runs measuring recession in the border and obtaining it by data analysis. Infiltration rate will be minimum at the end of recession for a given irrigation. Thereforc, $f_{c}$ is the instantancous infiltration rate at the end of $T_{2}$. However, the average rate at the end of $T_{2}$ may aso be taken as minimum rate. Since minimum rate is not clearly defined by $\mathrm{Wu},{ }^{12}$ we consider the following additional definitions designated as $f_{3}, f_{4}$ and $f_{5}$ :

$$
f_{3}=\frac{I_{3}}{T_{3}}, T_{3}=T_{1}-T_{L}, f_{4}=\frac{I_{2}}{T_{2}}, f_{5}=I_{r_{1}}, f_{c}=I_{r_{2}},
$$

where $I_{3}$ is the cumulative infiltration (m) at the end of $T_{3}(\mathrm{~s})$ and $T_{L}$ is the time of advance to the end of border (s). 


\subsubsection{Strelkoff model}

Strelkoff ${ }^{13}$ derived an algebraic relationship for the time of horizontal recession:

$$
t_{r}=\frac{S_{y}}{f_{s} F^{3 / 2}}\left(R_{L}-R_{l}\right)
$$

where the terms in Eqn (10) can be defined as

$$
\begin{gathered}
S_{y}=\frac{Y_{n}}{L}, \\
F=\frac{1}{n}\left(\frac{S_{0}^{1 / 2} S_{y}^{5 / 3}}{f_{s}}\right), \\
R_{L}=\int_{0}^{U_{z}} \frac{\mathrm{d} z}{1+z^{2 / 3}}, \\
U_{z}=F^{3 / 2} L, \\
R_{l}=\int_{0}^{U_{z_{1}}} \frac{\mathrm{d} z_{1}}{1+z_{1}^{2 / 3}}, \\
U_{z_{1}}=F^{3 / 2},
\end{gathered}
$$

where $Y_{n}$ is the normal depth of flow (m) corresponding to recession flow rate $q_{1}$ given in the Notation and $f_{s}$ is the average of infiltration rates at the upstream and downstream ends $(\mathrm{m} / \mathrm{s})$.

Eqn (10) requires evaluation of integrals as given by Eqns (13)-(16) as part of its solution. Although Strelkoff ${ }^{13}$ has given a graphical solution of these integrals, the solution of Eqn (10) is not amenable to a single calculation. The assumption of average rate of infiltration $f_{s}(\mathrm{~m} / \mathrm{s})$ as the average of instantaneous rates at the upstream and downstream ends is reasonable. We also considered the average of average infiltration rates at the upstream and downstream ends for comparison. These rates are defined as

$$
f_{s}=\frac{1}{2}\left(I_{r_{3}}+I_{r_{3}}\right), \quad f_{6}=\frac{1}{2}\left(\frac{I_{3}}{T_{3}}+\frac{I_{1}}{T_{1}}\right),
$$

where $I_{r_{3}}$ is the instantaneous infiltration rate $(\mathrm{m} / \mathrm{s})$ at the end of $T_{3}$.

\subsubsection{Singh-McCann model}

Singh and $\mathrm{McCann}{ }^{14}$ defined mathematical models for horizontal recession utilizing a spatially lumped form of continuity equation

$$
W f l=a\left(m_{0} S_{0}\right)^{\beta} l^{\beta} W=\frac{\mathrm{d} S}{\mathrm{~d} t}, \quad l(0)=L,
$$

and a storage discharge relationship of the form

$$
S=m_{0} S_{0} W l^{2},
$$

where $W$ is border width (m), $m_{\mathrm{o}}$ the slope constant, $f$ the constant infiltration rate and $S$ the surface storage $\left(\mathrm{m}^{3}\right)$. The recession models were developed by taking $\beta$ as $3 / 2$ and $5 / 3$, respectively as

$$
A_{1}\left(x_{r}^{0.5}-1\right)+B \ln \frac{A_{1}+B}{A_{1} x_{r}^{0.5}+B}=30 A_{1}^{2} t_{r}
$$


and

$$
\left(x_{r}{ }^{1 / 3}-1\right)+\sqrt{\frac{B}{A_{2}}}\left(\tan ^{-1} \sqrt{\frac{A_{2}}{B}}-\tan ^{-1} \sqrt{\frac{A_{2}}{B}} x_{r}{ }^{1 / 3}\right)=20 A_{2} t_{r},
$$

where $A_{1}, B$ and $A_{2}$ are constants as given in the Notation and $x_{r}$ is the ratio $l / L$.

The value of $m_{0}$ in Eqn (18) is not specified and should be determined by trial and error. In the present study its value was assumed to be $1 \cdot 0$. The constant infiltration rate $f$ was not defined. Therefore, Eqn (6) was used.

\subsubsection{Ram-Lal model}

\subsection{Empirical approach} time:

Ram and Lal ${ }^{15}$ proposed the following form of empirical relationship of horizontal recession

$$
t=\left[\frac{x Y_{0}^{r}}{K_{h} Y_{c}^{r}}\right]^{1 / b}
$$

where values of $K_{h}, r$ and $b$ were reported as $8 \cdot 17,0.775$ and $1 \cdot 16$, respectively, and $Y_{c}$ is the critical depth of flow. Eqn (22) is simple but does not explicitly account for infiltration; it is location specific. Its constants are strongly correlated with those in the Kostyakov infiltration equation. This equation was originally developed for the soil group with infiltration characteristics expressed by

$$
I=0.0003642 t_{i}^{0.808} \text {. }
$$

Eqn (22) may be used with appropriate values of $K_{h}, r$ and $b$ for specified soil characteristics.

\section{Recession of impounded water}

In borders with closed downstream ends, water becomes impounded against the bund, as shown in Fig. 2. Models to describe the recession of impounded water are considered below.

\subsection{Ram-Lal model}

Ram and $\mathrm{Lal}^{19}$ proposed the following relationship for calculation of recession time of impounded water:

$$
t_{r}=T_{0_{i}}-T+t_{x}
$$

where $T_{0_{t}}$ is the time of opportunity in the region of impounding and $T$ is the total time to the point where impounding starts (both in min). These quantities can be expressed as

$$
\begin{gathered}
T_{0_{i}}=\left[\frac{\left(x-x_{1}\right) S_{0}}{60^{a} K_{i}}+\left(T-t_{x}\right)^{a}\right]^{1 / a}, \\
T=\frac{t_{c}}{60}+t^{*}+t_{v}
\end{gathered}
$$

where $t_{c}$ is the time at which inflow is cut-off $(\mathrm{s}), x_{1}$ is the length of border $(\mathrm{m})$ to the point where impounding starts at the time $t^{*}(\mathrm{~min})$ and $t_{x}$ is the time of advance (min) for length $x$ in the region of impounding.

Eqn (24) is based on the assumption that after completion of horizontal recession water recedes only by infiltration, and there is no surface flow. This may not always be true, especially on steep slopes. 


\subsection{Strelkoff model}

Assuming a linear water surface profile at the end of vertical recession, Strelkoff ${ }^{13}$ expressed the approximate form of the volume balance as

$$
\frac{S_{0} L^{2}}{2}+\frac{I_{1}+I_{3}}{2} L=V_{0}
$$

where $V_{0}$ is the volume of inflow $\left(\mathrm{m}^{3}\right)$. Since $I_{1}$ is the cumulative infiltration at the end of $T_{1}$, Eqn (27) can be used to determine $T_{1}$ by trial and error. After completion of the vertical recession at time $T_{1}$, the recession length $x$ was expressed as

$$
x=\frac{I_{L}+I_{L-1}-I_{R}-I_{l}}{2 S_{0}}
$$

where $V_{0}, I_{L}, L_{L-l}, I_{R}$ and $I_{l}$ are as given in the Notation.

If the cut-off time of inflow is sufficiently large for a trapezoidal water volume to form on the surface, $T_{1}$ would be computed from Eqn (27). Assumptions of linear water surface profile for large times of inflow may be valid on relatively flat borders. However, these equations need field verification.

Separate relationships for computation of impounded water for small inflow times were developed by Strelkoff which need verification by field data.

\section{Model testing and discussion}

The mathematical models for vertical and horizontal recession were tested using irrigation data on open end borders by Roth. ${ }^{20}$ Four sets of data, designated as I, II, III and IV, on $q_{0}$, $S_{0}, K, n, C, K_{l}$ and $a$ were used as given in Table I. The depth of flow, $Y_{0}$, was used in recession models as calculated by Manning's equation. The models for recession of impounded water could not be tested due to lack of data.

It may be remarked that the data by $\operatorname{Roth}^{20}$ were selected as they contained all pertinent information required for comparison of these recession models. Unfortunately, such data are not easily available. It is realized that the testing of models performed in this study is based on this limited set of data, but is hoped that this study might encourage others to test and validate the various recession models using a wide variety of data.

\subsection{Models of vertical recession}

Table I shows observed times and the times calculated by the SWP, SCS and Strelkoff models [respectively, Eqns (1), (2) and (3)] for vertical recession. Table II gives the absolute and per cent deviations between observed and computed $t_{r}$ for each model. Results of each model are described below.

\subsubsection{SWP model}

Calculated and observed vertical recession times, as given in Table $I$, are in good agreement for the data sets I and IV. However, this is not the case with data sets II and III. The percentage differences, given in Table II, between calculated and observed times are as high as 302 for the data set II and 45 for the data set III. Thus, the model is not consistent in its performance. The borders for which calculations were made are on very flat slopes. Consequently, the assumption to remove the triangular volume of water at rate $q_{0}$ may not be valid. It is plausible that the model may give better results on steep slopes.

Absolute differences between observed and calculated vertical recession times are only $0 \cdot 18$, $2.42,1.36$ and $0.49 \mathrm{~min}$ compared with irrigation time of $181.4,179.7,179.0$ and $179.3 \mathrm{~min}$ for data sets I, II, III and IV, respectively. In such cases, the model may be used without adversely 

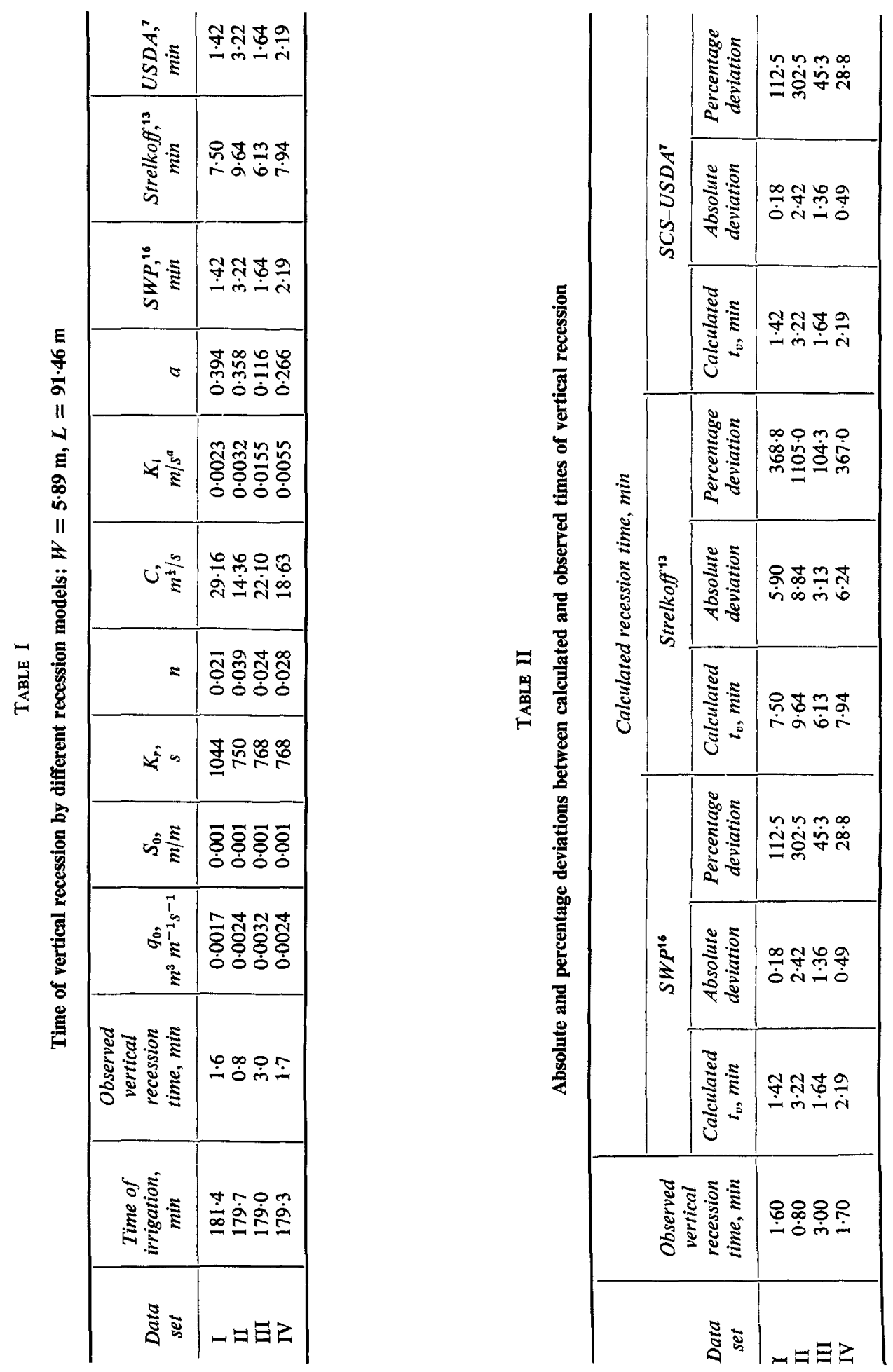
TABLE III

Time of horizontal recession by different recession models Data Set I: $f_{1}=2.86 \mathrm{~cm} / \mathrm{h}, f_{2}=1.13 \mathrm{~cm} / \mathrm{h}$

\begin{tabular}{|c|c|c|c|c|c|c|c|c|c|}
\hline \multirow{2}{*}{$\begin{array}{c}\text { Distance } \\
\text { from upstream } \\
\text { end, } m\end{array}$} & \multirow{2}{*}{$\begin{array}{l}\text { Observed } \\
\text { recession } \\
\text { time, min }\end{array}$} & \multicolumn{8}{|c|}{ Recession time (min) calculated from Eqn } \\
\hline & & (4) & (5) & $(20)$ & $(21)$ & (4) & (5) & $(20)$ & $(21)$ \\
\hline 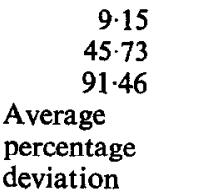 & $\begin{array}{r}5 \cdot 00 \\
14.00 \\
17 \cdot 00\end{array}$ & $\begin{array}{r}3 \cdot 85 \\
11 \cdot 27 \\
17 \cdot 88\end{array}$ & $\begin{array}{r}5 \cdot 36 \\
14 \cdot 07 \\
21 \cdot 33\end{array}$ & $\begin{array}{r}1.09 \\
6.19 \\
19.62\end{array}$ & $\begin{array}{r}0.77 \\
4 \cdot 60 \\
22 \cdot 28\end{array}$ & $\begin{array}{r}5 \cdot 26 \\
15 \cdot 36 \\
24 \cdot 39\end{array}$ & $\begin{array}{r}7 \cdot 78 \\
20 \cdot 43 \\
30 \cdot 96\end{array}$ & $\begin{array}{r}1 \cdot 11 \\
6 \cdot 32 \\
20 \cdot 75\end{array}$ & $\begin{array}{r}0.86 \\
5 \cdot 15 \\
24.97\end{array}$ \\
\hline
\end{tabular}

Data Set II: $f_{1}=2.89 \mathrm{~cm} / \mathrm{h}, f_{2}=1.03 \mathrm{~cm} / \mathrm{h}$

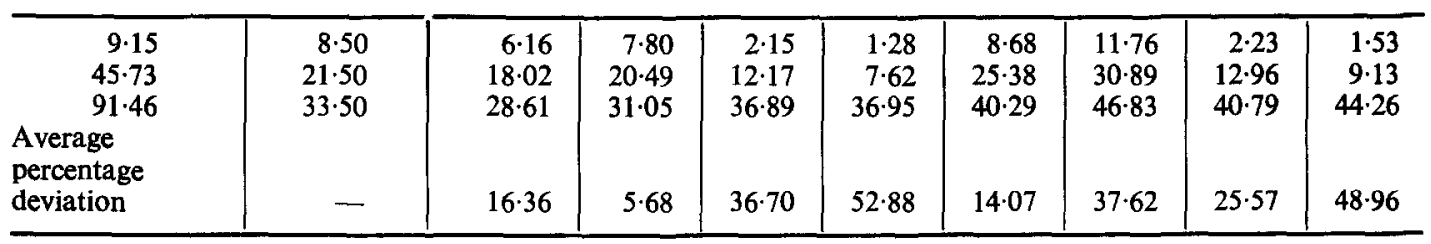

Data Set III: $f_{1}=1.30 \mathrm{~cm} / \mathrm{h}, f_{2}=0.14 \mathrm{~cm} / \mathrm{h}$

\begin{tabular}{|c|c|c|c|c|c|c|c|c|c|}
\hline $\begin{array}{l}9 \cdot 15 \\
45.73 \\
91.46 \\
\text { Average } \\
\text { percentage } \\
\text { deviation }\end{array}$ & $\begin{array}{r}6.00 \\
26.00 \\
41.00\end{array}$ & $\begin{array}{r}5 \cdot 83 \\
17 \cdot 05 \\
27 \cdot 06 \\
\\
26 \cdot 36\end{array}$ & $\begin{array}{r}7 \cdot 78 \\
20 \cdot 41 \\
30 \cdot 93 \\
\\
17 \cdot 96\end{array}$ & $\begin{array}{r}1 \cdot 32 \\
7 \cdot 54 \\
24 \cdot 60 \\
\\
\\
59 \cdot 95\end{array}$ & $\begin{array}{r}0 \cdot 88 \\
5 \cdot 27 \\
25 \cdot 58 \\
\\
66 \cdot 93\end{array}$ & $\begin{array}{l}12 \cdot 17 \\
35 \cdot 58 \\
56 \cdot 48 \\
\\
43 \cdot 81\end{array}$ & $\begin{array}{l}18 \cdot 79 \\
49 \cdot 35 \\
74 \cdot 80 \\
\\
98 \cdot 43\end{array}$ & $\begin{array}{r}1.34 \\
7.66 \\
25.93 \\
\\
\\
59 \cdot 24\end{array}$ & $\begin{array}{r}1.00 \\
5.97 \\
28.92 \\
\\
63.80\end{array}$ \\
\hline
\end{tabular}

Data Set IV: $f_{1}=2.03 \mathrm{~cm} / \mathrm{h}, f_{2}=0.54 \mathrm{~cm} / \mathrm{h}$

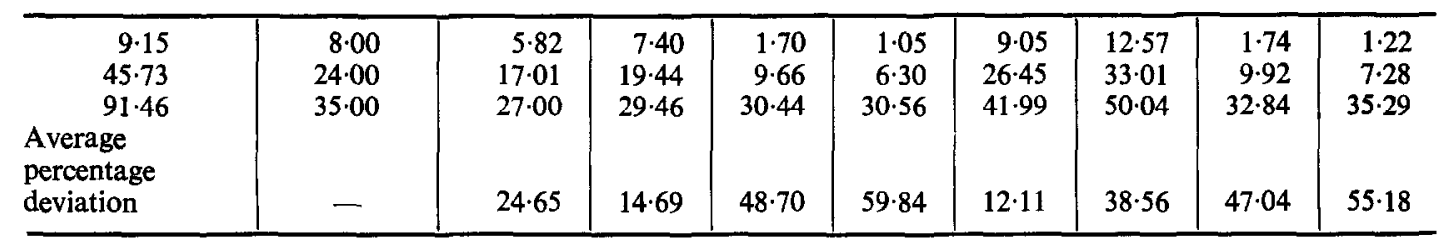

affecting the design of an irrigation system. However, care should be exercised where vertical recession times are large.

\subsubsection{SCS model}

This model is the same as the SWP model except that the depth of flow, $Y_{0}$, is expressed by Manning's equation. The results for this model are, therefore, the same as for the SWP model as is evident from Tables I and II.

\subsubsection{Strelkoff model}

The absolute differences between calculated and observed recession times for the data sets I, II, III and IV are 5.9, 8.84, 3.13 and $6.24 \mathrm{~min}$, respectively, as shown in Table II. These differences are very high. Thus, the model cannot be used at all for prediction purposes. If length $L$ is substituted by $Y_{0} / S_{0}$ in the model, the model will give the same results as the SWP model. 
TABLE IV

Time of horizontal recession by different recession models

Data Set I

\begin{tabular}{|c|c|c|c|c|c|c|c|c|}
\hline \multirow{4}{*}{$\begin{array}{l}\text { Distance from } \\
\text { upstream end, } \\
\text { min }\end{array}$} & \multirow{4}{*}{$\begin{array}{l}\text { Observed } \\
\text { recession time, } \\
\text { min }\end{array}$} & \multicolumn{7}{|c|}{ Recession time (min) calculated from Eqn } \\
\hline & & $(8)$ & (8) & (8) & $(8)$ & $(10)$ & $(10)$ & $(22)$ \\
\hline & & \multicolumn{7}{|c|}{ Infiltration rate, $\mathrm{cm} / \mathrm{h}$} \\
\hline & & $\begin{array}{c}f_{3} \\
(3 \cdot 47)\end{array}$ & $\begin{array}{c}f_{4} \\
(2.79)\end{array}$ & $\begin{array}{c}f_{5} \\
(1 \cdot 16)\end{array}$ & $\begin{array}{c}f_{c} \\
(I \cdot 10)\end{array}$ & $\begin{array}{c}f_{6} \\
(3 \cdot 20)\end{array}$ & $\begin{array}{c}f_{s} \\
(1 \cdot 26)\end{array}$ & - \\
\hline $\begin{array}{r}9 \cdot 15 \\
45 \cdot 73 \\
91 \cdot 46\end{array}$ & $\begin{array}{r}5.00 \\
14 \cdot 00 \\
17.00\end{array}$ & $\begin{array}{r}2.56 \\
13.57 \\
25.03\end{array}$ & $\begin{array}{r}2 \cdot 81 \\
15 \cdot 20 \\
28 \cdot 92\end{array}$ & $\begin{array}{r}3 \cdot 63 \\
21 \cdot 29 \\
47 \cdot 32\end{array}$ & $\begin{array}{r}3.67 \\
21.61 \\
48.59\end{array}$ & $\begin{array}{r}1.05 \\
5 \cdot 72 \\
13 \cdot 60\end{array}$ & $\begin{array}{r}1.37 \\
7.88 \\
22.75\end{array}$ & $\begin{array}{r}2.05 \\
8.25 \\
14.99\end{array}$ \\
\hline $\begin{array}{l}\text { Average } \\
\text { percentage } \\
\text { deviation }\end{array}$ & - & 26.02 & $32 \cdot 50$ & 74.84 & 77.60 & 47.50 & 35.79 & 32.22 \\
\hline
\end{tabular}

Data Set II

\begin{tabular}{|c|c|c|c|c|c|c|c|c|}
\hline & & $\begin{array}{c}f_{3} \\
(3 \cdot 59)\end{array}$ & $\begin{array}{c}f_{4} \\
(2 \cdot 73)\end{array}$ & $\begin{array}{c}f_{5} \\
(1 \cdot 09)\end{array}$ & $\begin{array}{c}f_{c} \\
(0 \cdot 98)\end{array}$ & $\begin{array}{c}f_{6} \\
(3 \cdot 32)\end{array}$ & $\begin{array}{c}f_{s} \\
(1 \cdot 19)\end{array}$ & - \\
\hline $\begin{array}{r}9.15 \\
45 \cdot 73 \\
91.46\end{array}$ & $\begin{array}{r}8.50 \\
21 \cdot 50 \\
33 \cdot 50\end{array}$ & $\begin{array}{r}2.98 \\
17 \cdot 73 \\
45 \cdot 33\end{array}$ & $\begin{array}{r}2.98 \\
18 \cdot 53 \\
50 \cdot 49\end{array}$ & $\begin{array}{r}3 \cdot 16 \\
20 \cdot 28 \\
68 \cdot 47\end{array}$ & $\begin{array}{r}3 \cdot 17 \\
20 \cdot 42 \\
70 \cdot 67\end{array}$ & $\begin{array}{r}1 \cdot 52 \\
8 \cdot 48 \\
21 \cdot 46\end{array}$ & $\begin{array}{r}1.85 \\
10 \cdot 74 \\
33 \cdot 22\end{array}$ & $\begin{array}{r}2 \cdot 61 \\
10 \cdot 47 \\
19 \cdot 05\end{array}$ \\
\hline $\begin{array}{l}\text { Average } \\
\text { percentage } \\
\text { deviation }\end{array}$ & - & $26 \cdot 54$ & 28.97 & 38.81 & $39 \cdot 94$ & $53 \cdot 55$ & 48.85 & $47 \cdot 82$ \\
\hline
\end{tabular}

Data Set III

\begin{tabular}{|c|c|c|c|c|c|c|c|c|}
\hline & & $\begin{array}{c}f_{3} \\
(l \cdot 65)\end{array}$ & $\underset{(1 \cdot 19)}{f_{4}}$ & $\begin{array}{c}f_{5} \\
(0 \cdot 16)\end{array}$ & $\begin{array}{c}f_{c} \\
(0 \cdot 1.3)\end{array}$ & $\begin{array}{c}f_{6} \\
(1 \cdot 54)\end{array}$ & $\begin{array}{c}f_{s} \\
(0 \cdot 17)\end{array}$ & - \\
\hline $\begin{array}{r}9 \cdot 15 \\
45 \cdot 73 \\
91 \cdot 46\end{array}$ & $\begin{array}{r}6 \cdot 00 \\
26 \cdot 00 \\
41 \cdot 00\end{array}$ & $\begin{array}{r}2.93 \\
17.86 \\
44.76\end{array}$ & $\begin{array}{r}3.04 \\
18.89 \\
51.11\end{array}$ & $\begin{array}{r}3.32 \\
21 \cdot 68 \\
92.58\end{array}$ & $\begin{array}{r}3 \cdot 33 \\
21 \cdot 76 \\
96 \cdot 40\end{array}$ & $\begin{array}{r}1.18 \\
6.89 \\
21.56\end{array}$ & $\begin{array}{r}1 \cdot 83 \\
10 \cdot 21 \\
35 \cdot 33\end{array}$ & $\begin{array}{r}2.07 \\
8.33 \\
15.14\end{array}$ \\
\hline $\begin{array}{l}\text { Average } \\
\text { percentage } \\
\text { deviation }\end{array}$ & - & 24.05 & $24 \cdot 71$ & $38 \cdot 36$ & 39.49 & $62 \cdot 72$ & $48 \cdot 51$ & $60 \cdot 16$ \\
\hline
\end{tabular}

Data Set IV

\begin{tabular}{|c|c|c|c|c|c|c|c|c|}
\hline & & $\begin{array}{c}f_{3} \\
(2 \cdot 60)\end{array}$ & $\begin{array}{c}f_{4} \\
(1.91)\end{array}$ & $\begin{array}{c}f_{5} \\
(0.58)\end{array}$ & $\begin{array}{c}f_{c} \\
(0 \cdot 51)\end{array}$ & $\begin{array}{c}f_{6} \\
(2 \cdot 38)\end{array}$ & $\begin{array}{c}f_{s} \\
(0.63)\end{array}$ & $=$ \\
\hline $\begin{array}{r}9.15 \\
45 \cdot 73 \\
91 \cdot 46\end{array}$ & $\begin{array}{r}8 \cdot 00 \\
24 \cdot 00 \\
35.00\end{array}$ & $\begin{array}{r}2 \cdot 88 \\
17 \cdot 41 \\
42 \cdot 41\end{array}$ & $\begin{array}{r}2.99 \\
18 \cdot 46 \\
48 \cdot 24\end{array}$ & $\begin{array}{r}3 \cdot 25 \\
20 \cdot 89 \\
72 \cdot 11\end{array}$ & $\begin{array}{r}3.26 \\
21 \cdot 04 \\
74 \cdot 79\end{array}$ & $\begin{array}{r}1 \cdot 37 \\
7.79 \\
21 \cdot 16\end{array}$ & $\begin{array}{r}1.63 \\
9.50 \\
32.19\end{array}$ & $\begin{array}{r}2 \cdot 24 \\
9 \cdot 21 \\
16 \cdot 75\end{array}$ \\
\hline $\begin{array}{l}\text { Average } \\
\text { percentage } \\
\text { deviation }\end{array}$ & - & $26 \cdot 82$ & $28 \cdot 35$ & $39 \cdot 32$ & $40 \cdot 60$ & 58.02 & $48 \cdot 28$ & $55 \cdot 32$ \\
\hline
\end{tabular}




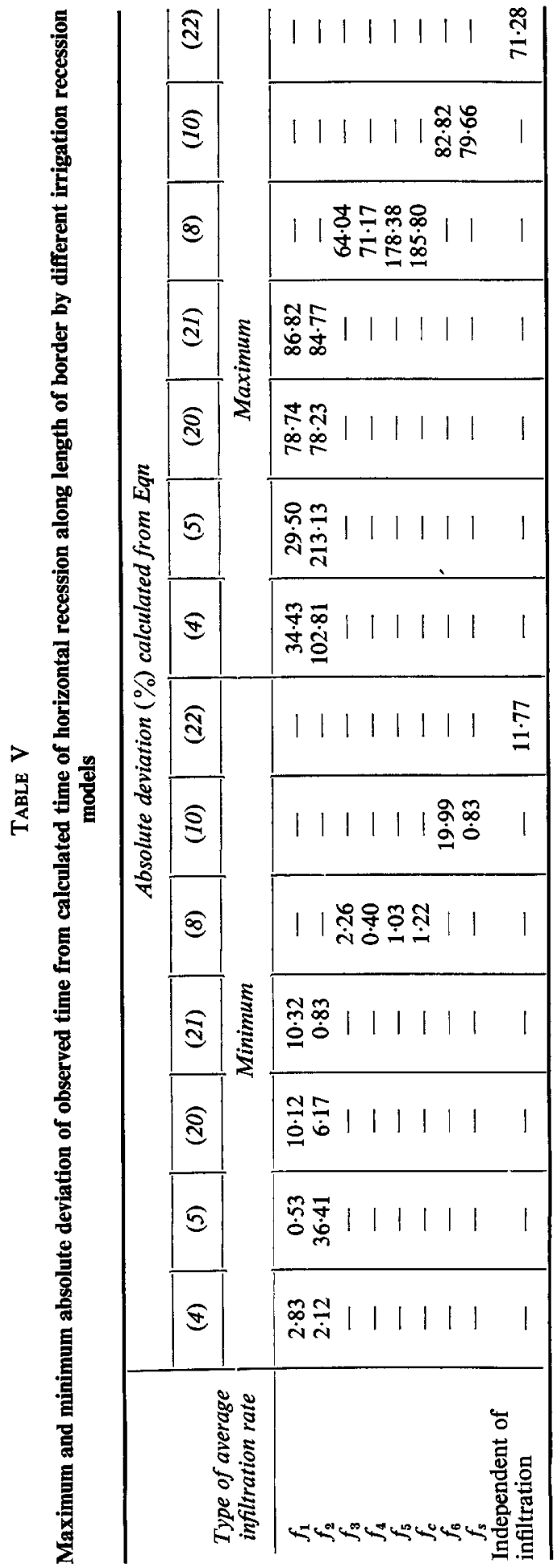




\subsection{Models of horizontal recession}

The times of horizontal recession were calculated for distances of $9 \cdot 15,18 \cdot 29,27 \cdot 44,36 \cdot 59$, $45 \cdot 73,54.88,64 \cdot 02,73 \cdot 17,82 \cdot 32$ and $91.46 \mathrm{~m}$ measured from the upstream end. However, to conserve space, calculated and observed times are given only for distances $9 \cdot 15,45 \cdot 73$ and $91.46 \mathrm{~m}$, as shown in Tables III and IV. The agreement between observed and computed times was measured in terms of maximum, minimum and average percentage deviations, as shown in Table V.

Using infiltration rates of $0 \cdot 1,0 \cdot 5,1 \cdot 0,1 \cdot 5,2 \cdot 0,3 \cdot 0,4 \cdot 0$ and $5 \cdot 0 \mathrm{~cm} / \mathrm{h}$, recession times were calculated for data set I by different recession models, and are given along with observed times in Table VI. Average percentage absolute deviations for all sets of data are given in Table VII. The results for different models are discussed below.

\subsubsection{Sherman-Singh model}

The Sherman-Singh model is given by Eqn (4) when Chezy's equation is used to express kinematic friction parameter $\alpha$. The model is given by Eqn (5) when $\alpha$ is expressed by Manning's equation. Calculated times by Eqn (4) are less than observed ones in almost all cases for infiltration rate $f_{1}$ (Table III). This is also true for Eqn (5) (Table III). The maximum and minimum percentage absolute deviations along the length of the border were found to be 2.83 and 34.43 from Eqn (4) and 0.53 and 29.50 from Eqn (5), as shown in Table V. The average absolute percentage deviation for different sets of data varied between 12.65 and 26.36 for Eqn (4) and 5.68 and 17.96 for Eqn (5) (Table V). However, the recession time was overestimated if $f_{2}$ was used. The results in Table $\mathrm{V}$ also show that the infiltration rate near $f_{1}$ is the best for recession models given by Eqns (4) and (5).

Both equations were found to be very sensitive to changes in infiltration rate. For example, the absolute percentage deviation for Eqn (4) varied between 9.96 for infiltration rate $2.0 \mathrm{~cm} / \mathrm{h}$ and 52.17 for $0.5 \mathrm{~cm} / \mathrm{h}$ for data set $\mathrm{I}$, as shown in Table VII. The increase in infiltration rate beyond $2.0 \mathrm{~cm} / \mathrm{h}$ led to increased error. Similar trends were observed for other sets of data. Eqn (5) also showed a similar trend. However, Eqn (5) gives better results than Eqn (4).

TABLE VI

Effect of infiltration rate on time of horizontal recession

Infiltration rate $0 \cdot 1 \mathrm{~cm} / \mathrm{h}$

\begin{tabular}{|c|c|c|c|c|c|c|c|c|}
\hline \multirow{2}{*}{$\begin{array}{l}\text { Distance from } \\
\text { upstream end, } \\
\qquad m\end{array}$} & \multirow{2}{*}{$\begin{array}{c}\text { Observed } \\
\text { recession time, } \\
\text { min }\end{array}$} & \multicolumn{7}{|c|}{ Recession time (min) calculated from Eqn } \\
\hline & & (4) & (5) & $(20)$ & $(2 l)$ & $(8)$ & $(10)$ & (22) \\
\hline $\begin{array}{l}9 \cdot 15 \\
45 \cdot 73 \\
91 \cdot 46 \\
\text { Average } \\
\text { percentage } \\
\text { deviation }\end{array}$ & $\begin{array}{r}5 \cdot 00 \\
14 \cdot 00 \\
17 \cdot 00\end{array}$ & $\begin{array}{r}11 \cdot 78 \\
34 \cdot 47 \\
54 \cdot 72 \\
153 \cdot 76\end{array}$ & $\begin{array}{l}20 \cdot 50 \\
53 \cdot 86 \\
81.63\end{array}$ & $\begin{array}{r}1 \cdot 12 \\
6 \cdot 39 \\
21 \cdot 71\end{array}$ & $\begin{array}{r}0.97 \\
5 \cdot 82 \\
28 \cdot 23\end{array}$ & $\begin{array}{r}4.48 \\
29 \cdot 08 \\
112 \cdot 67 \\
\\
177 \cdot 70\end{array}$ & $\begin{array}{r}2 \cdot 13 \\
11.98 \\
41 \cdot 93\end{array}$ & $\begin{array}{r}2.06 \\
8 \cdot 25 \\
14.99\end{array}$ \\
\hline \multicolumn{9}{|c|}{ Infiltration rate $0.5 \mathrm{~cm} / \mathrm{h}$} \\
\hline $\begin{array}{l}\quad 9 \cdot 15 \\
45 \cdot 73 \\
91 \cdot 46 \\
\text { Average } \\
\text { percentage } \\
\text { deviation }\end{array}$ & $\begin{array}{r}5.00 \\
14.00 \\
17 \cdot 00\end{array}$ & $\begin{array}{r}6 \cdot 89 \\
20 \cdot 16 \\
32 \cdot 00\end{array}$ & $\begin{array}{l}10 \cdot 77 \\
28 \cdot 29 \\
42 \cdot 88\end{array}$ & $\begin{array}{r}1 \cdot 12 \\
6 \cdot 37 \\
21 \cdot 28\end{array}$ & $\begin{array}{r}0.92 \\
5 \cdot 47 \\
26 \cdot 51\end{array}$ & $\begin{array}{r}4 \cdot 11 \\
25 \cdot 51 \\
68 \cdot 29\end{array}$ & $\begin{array}{r}1.52 \\
8.89 \\
29 \cdot 82\end{array}$ & $\begin{array}{r}2.06 \\
8.24 \\
14.99\end{array}$ \\
\hline
\end{tabular}


Infiltration rate $1.0 \mathrm{~cm} / \mathrm{h}$

\begin{tabular}{|c|c|c|c|c|c|c|c|c|}
\hline $\begin{array}{l}9 \cdot 15 \\
45 \cdot 73 \\
91.46 \\
\text { Average } \\
\text { percentage } \\
\text { deviation }\end{array}$ & $\begin{array}{r}5.00 \\
14.00 \\
17.00\end{array}$ & $\begin{array}{r}5 \cdot 47 \\
16 \cdot 00 \\
25 \cdot 40 \\
\\
\\
22 \cdot 65\end{array}$ & $\begin{array}{r}8 \cdot 16 \\
21 \cdot 44 \\
32 \cdot 49 \\
\\
61 \cdot 74\end{array}$ & $\begin{array}{r}1 \cdot 11 \\
6 \cdot 32 \\
8 \cdot 11 \\
\\
42 \cdot 40\end{array}$ & $\begin{array}{r}0 \cdot 87 \\
5 \cdot 20 \\
13 \cdot 52 \\
\\
50 \cdot 91\end{array}$ & $\begin{array}{r}3 \cdot 73 \\
22 \cdot 16 \\
50 \cdot 81 \\
\\
\\
82 \cdot 38\end{array}$ & $\begin{array}{r}1 \cdot 41 \\
8 \cdot 19 \\
24.69\end{array}$ & $\begin{array}{r}2.05 \\
8.26 \\
14.99 \\
\\
32.22\end{array}$ \\
\hline
\end{tabular}

Infiltration rate $1.5 \mathrm{~cm} / \mathrm{h}$

\begin{tabular}{l|r|r|r|r|r|r|r|r}
\hline \multicolumn{1}{c|}{$9 \cdot 15$} & 5.00 & 4.78 & 4.39 & $1 \cdot 10$ & 0.84 & 3.42 & 1.33 & 2.06 \\
$\begin{array}{l}45.73 \\
91.46\end{array}$ & 14.00 & $15 \cdot 78$ & 20.34 & 6.29 & 5.00 & 19.63 & 7.61 & 8.24 \\
$\begin{array}{l}\text { Average } \\
\text { percentage } \\
\text { deviation }\end{array}$ & 17.00 & 22.19 & 27.63 & 20.48 & 24.27 & 41.47 & 21.26 & 14.99 \\
\hline
\end{tabular}

Infiltration rate $2 \cdot 0 \mathrm{~cm} / \mathrm{h}$

\begin{tabular}{|c|c|c|c|c|c|c|c|c|}
\hline $\begin{array}{l}9.15 \\
45.73 \\
91.46 \\
\text { Average } \\
\text { percentage } \\
\text { deviation }\end{array}$ & $\begin{array}{r}5.00 \\
14.00 \\
17 \cdot 00\end{array}$ & $\begin{array}{r}4 \cdot 34 \\
12 \cdot 70 \\
20 \cdot 16\end{array}$ & $\begin{array}{r}6 \cdot 19 \\
16 \cdot 24 \\
24 \cdot 63\end{array}$ & $\begin{array}{r}1.09 \\
6.25 \\
20.16\end{array}$ & $\begin{array}{r}0.81 \\
4.84 \\
23.46\end{array}$ & $\begin{array}{r}3 \cdot 15 \\
17 \cdot 62 \\
35 \cdot 35\end{array}$ & $\begin{array}{r}1.25 \\
7.05 \\
18.58 \\
\\
\\
37.32\end{array}$ & $\begin{array}{r}2 \cdot 06 \\
8 \cdot 24 \\
14.99 \\
\\
32 \cdot 22\end{array}$ \\
\hline
\end{tabular}

Infiltration rate $3.0 \mathrm{~cm} / \mathrm{h}$

\begin{tabular}{|c|c|c|c|c|c|c|c|c|}
\hline $\begin{array}{l}9 \cdot 15 \\
45 \cdot 73 \\
91 \cdot 46 \\
\text { Average } \\
\text { percentage } \\
\text { deviation }\end{array}$ & $\begin{array}{r}5 \cdot 00 \\
14 \cdot 00 \\
17 \cdot 00\end{array}$ & $\begin{array}{r}3 \cdot 79 \\
11 \cdot 09 \\
17 \cdot 61 \\
\\
13 \cdot 29\end{array}$ & $\begin{array}{r}5.26 \\
13.82 \\
20.94\end{array}$ & $\begin{array}{r}1.09 \\
6 \cdot 18 \\
19 \cdot 55 \\
\\
42 \cdot 76\end{array}$ & $\begin{array}{r}0 \cdot 76 \\
4 \cdot 56 \\
22 \cdot 11 \\
\\
\\
53 \cdot 62\end{array}$ & $\begin{array}{r}2 \cdot 72 \\
14 \cdot 66 \\
27 \cdot 59 \\
\\
30 \cdot 10\end{array}$ & $\begin{array}{r}1.08 \\
5.95 \\
14.36 \\
\\
45.54\end{array}$ & $\begin{array}{r}2.06 \\
8 \cdot 24 \\
14.99\end{array}$ \\
\hline
\end{tabular}

Infiltration rate $4.0 \mathrm{~cm} / \mathrm{h}$

\begin{tabular}{|c|c|c|c|c|c|c|c|c|}
\hline $\begin{array}{l}\begin{array}{r}9.15 \\
45.73 \\
91.46\end{array} \\
\text { Average } \\
\text { percentage } \\
\text { deviation }\end{array}$ & $\begin{array}{r}5.00 \\
14.00 \\
17.00\end{array}$ & $\begin{array}{r}3 \cdot 45 \\
10 \cdot 08 \\
16 \cdot 01 \\
\\
\\
19 \cdot 37\end{array}$ & $\begin{array}{r}4 \cdot 69 \\
12 \cdot 32 \\
18 \cdot 66\end{array}$ & $\begin{array}{r}1.08 \\
6.11 \\
19 \cdot 02 \\
\\
42.98\end{array}$ & $\begin{array}{r}0.72 \\
56 \cdot 32 \\
21 \cdot 07\end{array}$ & $\begin{array}{r}2 \cdot 04 \\
12 \cdot 56 \\
22 \cdot 76 \\
\\
23 \cdot 21\end{array}$ & $\begin{array}{r}0.91 \\
4.84 \\
10.94\end{array}$ & $\begin{array}{r}2.06 \\
8.24 \\
14.99\end{array}$ \\
\hline
\end{tabular}

Infiltration rate $5.0 \mathrm{~cm} / \mathrm{h}$

\begin{tabular}{c|r|r|r|r|r|r|r|r}
\hline \multicolumn{1}{c|}{$9 \cdot 15$} & 5.00 & 3.20 & $4 \cdot 29$ & 1.07 & 0.69 & $2 \cdot 15$ & 0.69 & 2.06 \\
$\begin{array}{c}45.73 \\
91.46\end{array}$ & 14.00 & 9.36 & 11.26 & 6.05 & 4.13 & 10.99 & 3.65 & 8.24 \\
$\begin{array}{l}\text { Average } \\
\text { percentage } \\
\text { deviation }\end{array}$ & 17.00 & 14.85 & 17.07 & 18.54 & 20.04 & 19.42 & 7.84 & 14.99 \\
\hline
\end{tabular}


TABLE VII

Effect of infiltration rate on percentage deviation between observed and calculated times of horizontal recession

\begin{tabular}{|c|c|c|c|c|c|c|c|c|}
\hline \multirow[b]{2}{*}{ Data set } & \multirow{2}{*}{$\begin{array}{l}\text { Infiltration } \\
\text { rate, } \mathrm{cm} / \mathrm{h}\end{array}$} & \multicolumn{7}{|c|}{ Average deviation $(\%)$ from Eqn } \\
\hline & & (4) & (5) & $(20)$ & $(2 I)$ & (8) & $(10)$ & $(22)$ \\
\hline I & $\begin{array}{l}0.1 \\
0.5 \\
1.0 \\
1 \cdot 5 \\
2 \cdot 0 \\
3.0 \\
4 \cdot 0 \\
5.0\end{array}$ & $\begin{array}{r}153 \cdot 76 \\
52 \cdot 17 \\
22 \cdot 66 \\
10 \cdot 16 \\
9 \cdot 96 \\
13 \cdot 29 \\
19 \cdot 36 \\
24 \cdot 49\end{array}$ & $\begin{array}{r}292 \cdot 52 \\
110 \cdot 51 \\
61 \cdot 74 \\
38 \cdot 88 \\
24 \cdot 77 \\
7 \cdot 75 \\
7 \cdot 20 \\
10 \cdot 83\end{array}$ & $\begin{array}{l}42 \cdot 37 \\
42 \cdot 36 \\
42 \cdot 41 \\
42 \cdot 48 \\
42 \cdot 56 \\
42 \cdot 76 \\
42 \cdot 98 \\
43 \cdot 22\end{array}$ & $\begin{array}{l}48 \cdot 32 \\
49 \cdot 81 \\
50 \cdot 92 \\
51 \cdot 75 \\
52 \cdot 45 \\
53 \cdot 61 \\
54 \cdot 58 \\
55 \cdot 41\end{array}$ & $\begin{array}{r}177 \cdot 70 \\
117 \cdot 38 \\
82 \cdot 38 \\
61 \cdot 52 \\
46 \cdot 73 \\
30 \cdot 10 \\
23 \cdot 21 \\
21 \cdot 45\end{array}$ & $\begin{array}{l}41 \cdot 56 \\
37 \cdot 39 \\
35 \cdot 72 \\
35 \cdot 96 \\
37 \cdot 31 \\
45 \cdot 53 \\
54 \cdot 80 \\
64 \cdot 09\end{array}$ & $\begin{array}{l}32 \cdot 22 \\
32 \cdot 22 \\
32 \cdot 22 \\
32 \cdot 22 \\
32 \cdot 22 \\
32 \cdot 22 \\
32 \cdot 22 \\
32 \cdot 22\end{array}$ \\
\hline II & $\begin{array}{l}0.1 \\
0.5 \\
1.0 \\
1.5 \\
2.0 \\
3.0 \\
4.0 \\
5.0\end{array}$ & $\begin{array}{r}137 \cdot 81 \\
42.85 \\
15 \cdot 25 \\
4.08 \\
6.64 \\
17 \cdot 29 \\
24.03 \\
28.82\end{array}$ & $\begin{array}{r}236.31 \\
80.98 \\
39.96 \\
19.86 \\
7.82 \\
6.96 \\
16.08 \\
22.47\end{array}$ & $\begin{array}{l}35 \cdot 21 \\
35 \cdot 32 \\
35 \cdot 55 \\
35 \cdot 83 \\
36 \cdot 13 \\
36 \cdot 77 \\
37 \cdot 43 \\
38 \cdot 08\end{array}$ & $\begin{array}{l}44 \cdot 76 \\
47 \cdot 11 \\
48 \cdot 85 \\
50 \cdot 17 \\
51 \cdot 27 \\
53 \cdot 05 \\
54 \cdot 51 \\
56 \cdot 76\end{array}$ & $\begin{array}{l}58 \cdot 22 \\
46 \cdot 24 \\
39 \cdot 70 \\
35 \cdot 37 \\
32 \cdot 11 \\
28 \cdot 12 \\
25 \cdot 71 \\
25 \cdot 01\end{array}$ & $\begin{array}{l}29 \cdot 01 \\
38 \cdot 20 \\
40 \cdot 14 \\
43 \cdot 03 \\
46 \cdot 20 \\
51 \cdot 85 \\
57 \cdot 01 \\
61 \cdot 93\end{array}$ & $\begin{array}{l}47 \cdot 82 \\
47 \cdot 82 \\
47 \cdot 82 \\
47 \cdot 82 \\
47 \cdot 82 \\
47 \cdot 82 \\
47 \cdot 82 \\
47 \cdot 82\end{array}$ \\
\hline III & $\begin{array}{l}0 \cdot 1 \\
0 \cdot 5 \\
1 \cdot 0 \\
1 \cdot 5 \\
2 \cdot 0 \\
3 \cdot 0 \\
4 \cdot 0 \\
5 \cdot 0\end{array}$ & $\begin{array}{r}61 \cdot 08 \\
9.29 \\
21 \cdot 48 \\
29.28 \\
34.91 \\
41.99 \\
46.46 \\
49.65\end{array}$ & $\begin{array}{r}127 \cdot 92 \\
24.04 \\
13 \cdot 47 \\
20 \cdot 92 \\
26 \cdot 55 \\
34 \cdot 77 \\
40 \cdot 87 \\
45 \cdot 14\end{array}$ & $\begin{array}{l}59 \cdot 21 \\
59 \cdot 48 \\
59 \cdot 78 \\
60 \cdot 06 \\
60 \cdot 33 \\
60 \cdot 83 \\
61 \cdot 31 \\
61 \cdot 76\end{array}$ & $\begin{array}{l}63 \cdot 53 \\
65 \cdot 18 \\
66 \cdot 34 \\
67 \cdot 27 \\
68 \cdot 02 \\
69 \cdot 28 \\
70 \cdot 33 \\
71 \cdot 24\end{array}$ & $\begin{array}{l}41 \cdot 09 \\
30 \cdot 30 \\
25 \cdot 41 \\
23 \cdot 92 \\
24 \cdot 86 \\
32 \cdot 79 \\
38 \cdot 81 \\
43 \cdot 57\end{array}$ & $\begin{array}{l}38 \cdot 81 \\
57 \cdot 82 \\
60 \cdot 85 \\
62 \cdot 59 \\
64 \cdot 02 \\
66 \cdot 50 \\
68 \cdot 72 \\
70 \cdot 80\end{array}$ & $\begin{array}{l}60 \cdot 16 \\
60 \cdot 16 \\
60 \cdot 16 \\
60 \cdot 16 \\
60 \cdot 16 \\
60 \cdot 16 \\
60 \cdot 16 \\
60 \cdot 16\end{array}$ \\
\hline IV & $\begin{array}{l}0 \cdot 1 \\
0.5 \\
1 \cdot 0 \\
1 \cdot 5 \\
2 \cdot 0 \\
3 \cdot 0 \\
4 \cdot 0 \\
5 \cdot 0\end{array}$ & $\begin{array}{r}90 \cdot 08 \\
14.93 \\
6.89 \\
17 \cdot 51 \\
24 \cdot 22 \\
32 \cdot 66 \\
37.98 \\
41 \cdot 77\end{array}$ & $\begin{array}{r}163 \cdot 65 \\
42 \cdot 81 \\
10 \cdot 43 \\
5 \cdot 57 \\
14 \cdot 10 \\
25 \cdot 60 \\
32 \cdot 70 \\
37 \cdot 67\end{array}$ & $\begin{array}{l}46 \cdot 45 \\
46.98 \\
47 \cdot 58 \\
48 \cdot 13 \\
48 \cdot 66 \\
49 \cdot 64 \\
50 \cdot 55 \\
51 \cdot 40\end{array}$ & $\begin{array}{l}53 \cdot 72 \\
55 \cdot 08 \\
56 \cdot 88 \\
58 \cdot 44 \\
59 \cdot 75 \\
61 \cdot 89 \\
63 \cdot 65 \\
65 \cdot 17\end{array}$ & $\begin{array}{l}53 \cdot 79 \\
40 \cdot 73 \\
34 \cdot 19 \\
30 \cdot 49 \\
27 \cdot 93 \\
26 \cdot 38 \\
28 \cdot 11 \\
33 \cdot 16\end{array}$ & $\begin{array}{l}34 \cdot 50 \\
46 \cdot 87 \\
50 \cdot 99 \\
53 \cdot 83 \\
56 \cdot 28 \\
60 \cdot 64 \\
64 \cdot 61 \\
68 \cdot 39\end{array}$ & $\begin{array}{l}55 \cdot 32 \\
55 \cdot 32 \\
55 \cdot 32 \\
55 \cdot 32 \\
55 \cdot 32 \\
55 \cdot 32 \\
55 \cdot 32 \\
55 \cdot 32\end{array}$ \\
\hline
\end{tabular}

\subsubsection{Wu model}

The Wu model [Eqn (8)] underestimated the horizontal recession time in the beginning of the border and overestimated towards the end for all sets of data, as shown in Table IV. The minimum infiltration rate $f_{c}\left(\mathrm{Wu}^{12}\right)$, as given by Eqn (9), resulted in inferior results compared with the one when $f_{3}$ [given by Eqn (9)], which is the average infiltration rate at the downstream end of the border, was used as infiltration capacity. This indicates that the proper selection of an infiltration rate may give better results for the same recession model. Changes in infiltration rate improved the results significantly (Table V). For infiltration rate $f_{c}(1 \cdot 1 \mathrm{~cm} / \mathrm{h})$ the average absolute deviation was $77.6 \%$ which dropped to $21.46 \%$ when an average rate of $5.0 \mathrm{~cm} / \mathrm{h}$ was used for data set I (Table VII). This is comparable with the results with $f_{3}$ (deviation $26.02 \%$ ). It is, therefore, advisable to use $f_{3}$ as the infiltration rate. 


\subsubsection{Strelkoff model}

The Strelkoff model [Eqn (10)] underestimated the recession time throughout the border length for almost all sets of data (Table IV). It gives better results with infiltration rate $f_{s}$, expressed by Eqn (17), compared with the results with $f_{6}$. However, Tables VI and VII show that the model was not very sensitive to changes in infiltration rates.

\subsubsection{Singh-McCann model}

The Singh-McCann model is given by Eqn (20) when $\alpha$ and $\beta$ are expressed by Chezy's equation. Similarly, this model is given by Eqn (21) when $\alpha$ and $\beta$ are expressed by Manning's equation. Both equations underestimated the time of horizontal recession for almost all sets of data and all points along the length of the border (Table III). Calculated times in the beginning of the border were too small compared with observed times. However, these times improved considerably towards the end for both Eqns (20) and (21). The maximum, minimum and average percentage absolute deviations (Table VII) indicate that there is a wide range of variations between calculated and observed recession times. Even the changes in infiltration rate did not influence the results significantly (Tables VI and VII).

\subsubsection{Ram-Lal model}

The Ram-Lal model [Eqn (22)], which is purely an empirical equation, does not account for infiltration. The average absolute percentage deviations for different sets of data were between 32.2 and 60.16 (Table IV), while the minimum and maximum deviations were 11.77 and $71.28 \%$ among all 4 sets of data (Table V). The results may improve if recession constants developed for local conditions are used in the model.

\section{Comparison of models}

Among all models for determination of the time of horizontal recession, the Sherman-Singh model ( $\alpha$ expressed by Manning's equation) predicted recession time most closely, followed by the same model for $\alpha$ expressed by Chezy's equation with $f_{1}$ as the infiltration rate. In order of accuracy of predictions on the basis of average absolute percentage deviation, the ShermanSingh model was followed by the Strelkoff model with $f_{5}$, the Singh-McCann model with $\alpha_{1}$ and $f_{1}$, the Ram-Lal model, the Wu model with $f_{c}$ and the Singh-McCann model with $\alpha_{2}$ and $f_{2}$. However, when $f_{3}$ was used in the $\mathrm{Wu}$ model, it gave better results than the Singh-McCann, Strelkoff and Ram-Lal models. Similarly, in order of sensitivity to infiltration, these models can be ranked as the Sherman-Singh, Strelkoff, Wu, Singh-McCann and Ram-Lal models.

\section{Conclusion}

The Sherman-Singh model predicted horizontal recession time reasonably well, within $29.5 \%$ of deviation from the observed time, provided the average of average infiltration rates at the end of completion of vertical and horizontal recession times is used and the kinematic friction parameter is expressed by Manning's equation. The Wu model also gave predictions with $45 \cdot 3 \%$ of accuracy, if minimum infiltration rate is taken as average infiltration rate at the lower end of the border after completion of vertical recession. The Singh-McCann model and the Strelkoff model are simple and can be used within an accuracy of $85 \%$ deviation from observed data.

The Sherman-Singh model is sensitive to infiltration and may result in poor results if infiltration parameters are not estimated accurately while the Singh-McCann model, the Strelkoff model and the Wu model are not as sensitive. The Ram-Lal model gave results within $60 \%$ of observed recession times. The results may be improved by accurate estimation of empirical constants in the equation. 
Vertical recession was not predicted accurately by any of the models. However, the SWP model may be used in irrigation system design without undue restriction because the vertical recession time is usually very small compared with the time of irrigation.

It should be emphasized that the above conclusions are based on a set of limited experimental data presented by Roth. ${ }^{20}$ Therefore, these recession models need to be tested further and compared using a variety of data before more definitive conclusions can be reached. However, it may be appropriate to note that the conclusions reached in this study are in support of those reached in individual model developments.

Models for recession of impounded water in closed downstream borders need field evaluation for short and long time of inflow cut-off.

\section{Acknowledgement}

This study was supported in part by funds provided by the National Science Foundation under the project "Free Boundary Problems in Water Resource Engineering", NSF-ENG-79-23345.

\section{REFERENCES}

1 Chen, C. L. Techniques of border irrigation by a hydrological method of routing. Rep. PR-WR11-1, Utah Water Research Laboratory, Utah State University, Logan, Utah, 1965

2 Ram, R. S. Hydraulics of recession flow in border irrigation system. Thesis submitted to the Indian Institute of Technology, Kharagpur, for the Degree of Master of Technology in Agricultural Engineering, 1969

3 Sherman, B.; Singh, V. P. A kinematic model for surface irrigation. Wat. Resources Res., 197814 (2) 357-364

${ }^{4} \mathrm{Su}, \mathrm{H}$. H. Hydraulics of unsteady, open-channel flow over a porous bed. Thesis submitted to Utah State University for the Degree of Master of Science in Civil Engineering, 1962

5 Schreiber, D. L.; Bassett, D. L. Hydraulic description of recession of shallow flow over a porous bed. Trans. Am. Soc. agric. Engrs, 196710 (1) 54-56, 61

6 Bassett, D. L.; Fitzsimmons, D. W. Simulating overland flow in border irrigation. Trans. Am. Soc. agric. Engrs, 197619 (4) 666671

7 Katopodes, N. D.; Strelkoff, T. Hydrodynamics of border irrigation-complete model. J. Irrig. Drainage Divn, Proc. Am. Soc. civ. Engrs, 1977 103(IR3) 309-323

- Clemmens, A. J.; Strelkoff, T. Dimensionless advance for level basin irrigation. J. Irrig. Drainage Divn, Proc. Am. Soc. civ. Engrs, 1979 105(IR3) 259-273

- Cunge, J. S.; Woolhiser, D. A. Irrigation systems. In Unsteady Flow in Open Channels (Mahmood, K. and Yevjevich, V., Eds), Vol. 2, Chapter 13. Fort Collins, Colorado: Water Resources Publications, 1975 pp. $509-537$

10 Strelkoff, T.; Katapodes, N. D. Border irrigation hydraulics with zero-inertia. J. Irrig. Drainage Divn, Proc. Am. Soc. civ. Engrs, 1977 103(IR3) 325-342

11 Fangmeier, D. D.; Strelkoff, T. Mathematical models and border irrigation design. Trans. Am. Soc. civ. Engrs, 197922 (1) 93-99

12 Wu, I-Pai Recession flow in surface irrigation. J. Irrig. Drainage Divn, Proc. Am. Soc. civ. Engrs, 1972 98(IR9) 77-89

13 Strelkoff, T. Algebraic computation of flow in border irrigation. J. Irrig. Drainage Divn, Proc. Am. Soc. civ. Engrs, 1977 103(IR3) 357-377

14 Singh, V. P.; McCann, R. C. Mathematical modeling of hydraulics of irrigation recession. Proc. Second Int. Conf. Mathematical Modeling, St Louis, Missouri, 11-13 July 1979

is Ram, R. S.; Lal, R. Recession flow in border irrigation. J. Agric. Engng, ISAE, 19718 (3) 62-70

i6 Schockley, D. G.; Woodward, H. J.; Phelan, J. T. Quasi-rational method of border irrigation design. Trans. Am. Soc. agric. Engrs, 19647 (4) 420-423

17 U.S. Soil Conservation Service Border irrigation. In National Engineering Handbook, Chapter 4, Section 15. USDA, SCS, 1974. 
18 Kostyakov, A. N. On the dynamics of the coefficient of water percolation in soils and of the necessity of studying it from a dynamic point of view for purposes of amelioration. Trans. Sixth Commission Int. Soc. Soil Sci., 17-21, 1932 (in Russian)

19 Ram, R. S.; Lal, R. Recession of impounded water in an irrigated border with closed downstream end. The Harvester (I.I.T. Kharagpur, India), $19692206-210$

20 Roth, R. L. Roughness during border irrigation. Thesis submitted to the University of Arizona for the Degree of Master of Science in Agricultural Engineering, 1971 